\title{
TATA INSTITUTE RADIOCARBON DATE LIST IX
}

\author{
D. P. AGRAWAL, S. K. GUPTA, and SHEELA KUSUMGAR
}

Tata Institute of Fundamental Research, Bombay-5, India

The $\mathrm{C}^{14}$ dates given below are in years B.P. calculated on the basis of $\tau_{1 / 2}=5568$ years. For converting to A.D./B.C scale, 1950 was used as reference year. Ninety-five per cent activity of NBS oxalic acid was used as a modern standard.

Radiocarbon activity was counted after converting sample carbon into methane gas (Agrawal et al., 1965). Up to now, we used the synthesis technique developed by Anand and Lal (1964) in which the sample $\mathbf{C O}_{2}$ and appropriate amounts of zinc and water (tritium-free) are allowed to react in the presence of ruthenium catalyst inside a reaction vessel with temperature zones of $430^{\circ}$ and $500^{\circ} \mathrm{C}$. In the reaction,

$$
\mathrm{CO}_{2}+2 \mathrm{H}_{2} \mathrm{O}+4 \mathrm{Zn}=\mathrm{CH}_{4}+4 \mathrm{ZnO}
$$

a continuous hydrogen supply, until completion of the reaction, is provided by water reacting with zinc powder maintained at $430^{\circ} \mathrm{C}$. Thus, reaction (1) is, in principle, the same as originally employed by Burke and Meinschein (1955),

$$
\mathrm{CO}_{2}+4 \mathrm{H}_{2}=\mathrm{CH}_{4}+2 \mathrm{H}_{2} \mathrm{O}
$$

as far as synthesis of methane for counting $\mathrm{C}^{14}$ activity is concerned. Reaction (2) leads to an incomplete conversion of hydrogen and is, therefore, not satisfactory for methane synthesis for $\mathrm{H}^{3}$ measurement.

Reaction (2) was successfully used for the first time by Fairhall et al. (1961) for radiocarbon measurements. Subsequent modifications were reported by Olson and Nickloff (1965) and Polach and Stipp (1967). Techniques employing reaction (2) are in use in several $\mathrm{C}^{14}$ laboratories. We now use reaction (2) as such for methane synthesis in our laboratory and briefly describe here apparatus and experimental techniques, since our procedures lead to fairly routine, simple, and quick analyses with yields better than $99 \%$. The prime reason for adopting this system was that we occasionally discovered that synthesized methane was contaminated with artificial tritium used in the TIFR laboratories. The technique adopted for reaction (1) involved opening the reaction vessel for every synthesis for replacing consumed zinc and introducing the water ampule; frequently, it also became necessary to remove spilled fragments of pyrex glass (from the fragmented ampules) and grains of zinc oxide. In the system described below, the reaction vessel is not opened and all that is required is introduction of the sample $\mathrm{CO}_{2}$ in the reaction vessel; the $\mathrm{CO}_{2}$ is let in through a cold trap (dry ice + acetone) to remove any traces of water.

Our reactor vessel which, in some respects, resembles that used by Oeschger (pers. commun.) has a volume of $26 \mathrm{~L}$; it is made of hemispherical stainless steel vessels with flanges on their rims (Fig. 1). At the bottom is a stainless steel finger $(\mathrm{X})$, diam. $3.81 \mathrm{~cm}$ and length $15.24 \mathrm{~cm}$. 
The heater tray (A) for the catalyst consists of a platinum coil encased in quartz tubes and is placed in a perforated silver box (see inset plan of heater tray in Fig. 1). The catalyst is spread over the heater to expose maximum surface area. Electrical heat is provided through 2 ceramicmetal hermetic seals connected to the body of the reactor. The two reactor parts are closed with a teflon O-ring $(G)$, placed in the groove on

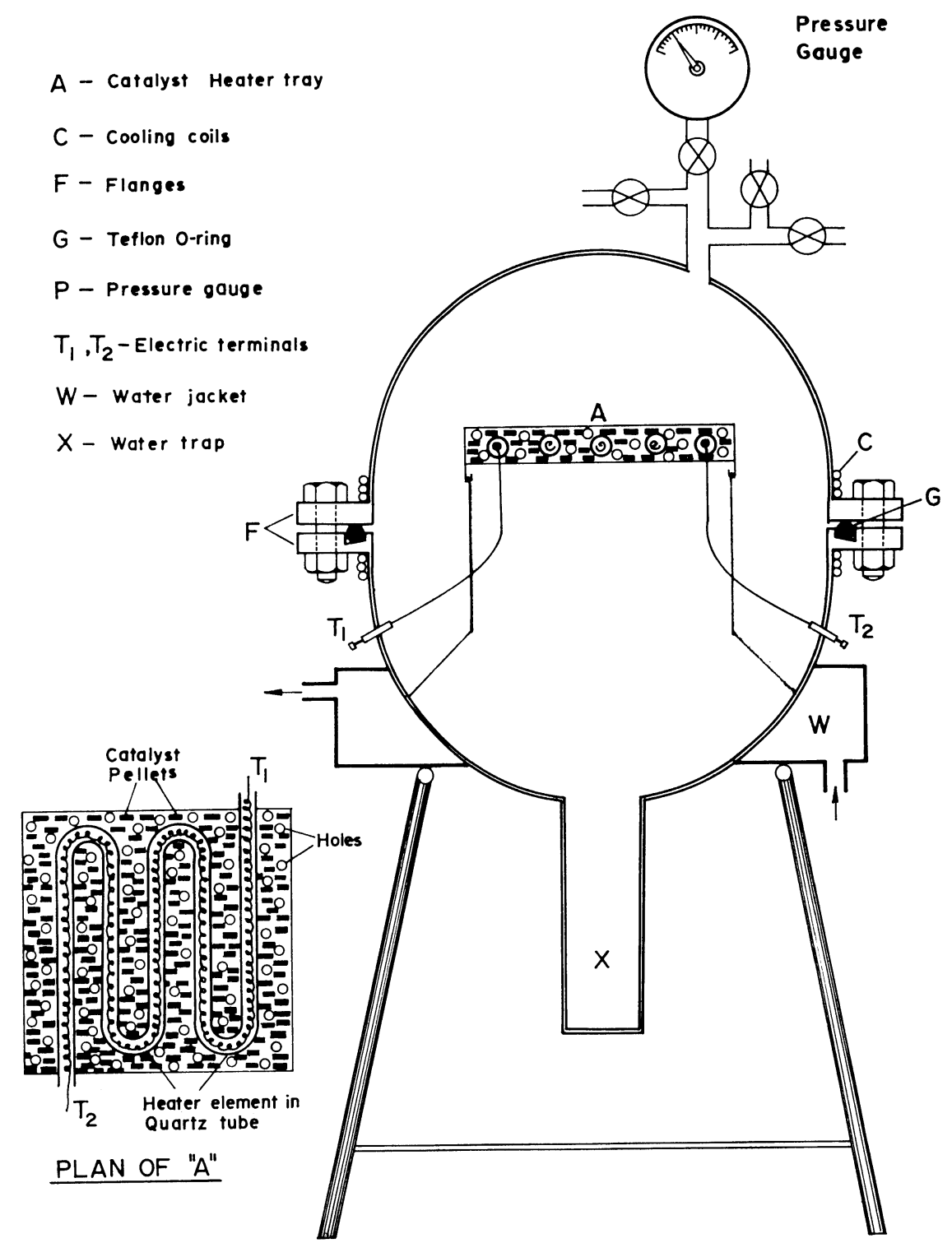

Fig. 1. Diagram showing the construction design of the reactor used for methane svnthesis. 
the flanges. The flanges are cooled by water circulating through copper tubes brazed on to the flange. The reactor assembly is placed on a watercooled jacket $(\mathrm{W})$ to speed up condensation of any water draining to the trap X. For a synthesis, $\mathrm{CO}_{2}$ and $\mathrm{H}_{2}$ corresponding to $20 \%$ excess over the stoichiometric requirement are let into the reactor and the catalyst tray is heated to ca. $450^{\circ} \mathrm{C}$.

Reaction rate can be seen from the pressure vs. time curve (Fig. 2). Maximum pressure in the vessel is reached in 20 minutes. At this point, Trap X (Fig. 1) is cooled with dry ice to remove water that is formed. Drop in pressure is very fast after 35 minutes and reaction is complete in about 3 hours, even with a large sample $\left(10 \mathrm{~L} \mathrm{CO}_{2}\right)$.

The reaction products are successively let through 3 dry-ice traps (to remove all traces of $\mathrm{H}_{2} \mathrm{O}$ ), 2 liquid- $\mathrm{N}_{2}$-cooled traps and a liquid- $\mathrm{N}_{2}$-cooled U-tube, filled with silica gel* (12-28 mesh) and here called S. The reactor is fairly quickly emptied by gentle pumping on the leading end of S. No methane is lost from $S$ provided the quantity of silica gel exceeds $7 \mathrm{~g}$ per liter of $\mathrm{CH}_{4}$. For purification of methane, pumping with a rotary pump is continued on the leading end of $\mathrm{S}$ for 40 to 50 mins. until most of the hydrogen is removed. Distillation of methane into $S$ from traps 1 and 2 is then allowed to proceed for an hour, with pumping on the leading end of $\mathrm{S}$ alternating, at 15-min. intervals, with connection beyond $\mathrm{S}$ to a liquid- $\mathrm{N}_{2}$-cooled activated-charcoal trap. Any remaining hydrogen is completely removed during this procedure.

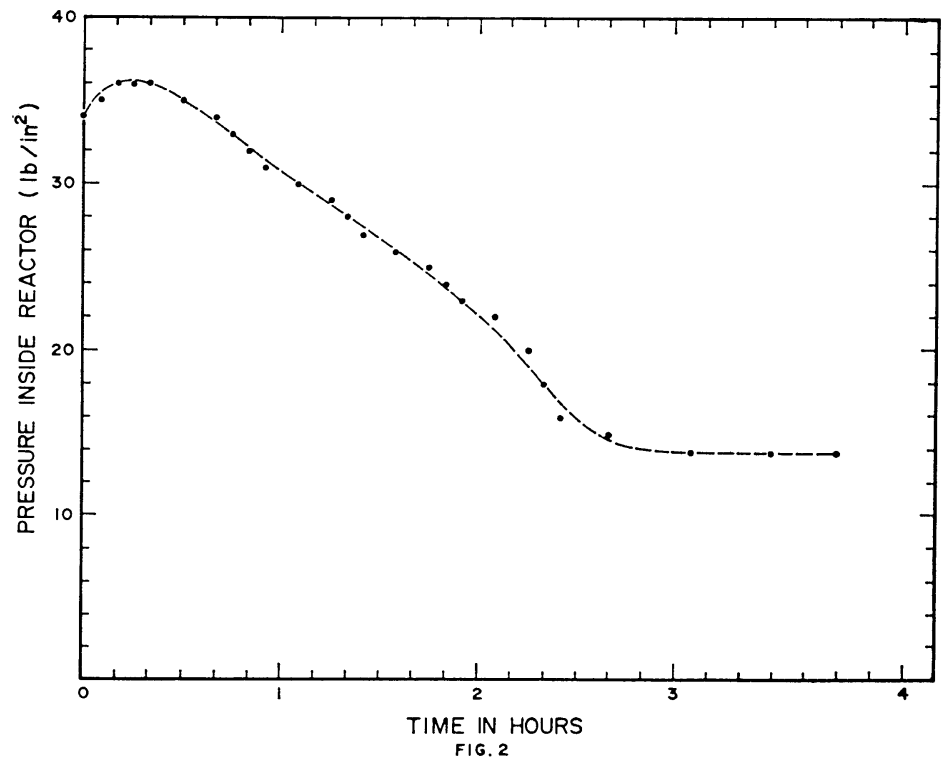

Fig. 2. Typical pressure vs. time curve for methane synthesis from $9 \mathrm{~L} \mathrm{CO}_{2}$. Initial pressure in the reactor $=34 \mathrm{lbs}$. $/ \mathrm{sq}$. in. at $\mathrm{t}=0$ when the catalyst heater tray is switched on.

* Davison Chemical, Baltimore 3, Maryland, U.S.A. 
The methane so purified is then expanded into flasks. Recovery is 98 to $99 \%$; 1 to $2 \%$ loss is attributed to pumping and not to incomplete conversion. The undistilled portion remaining in the traps 1 and 2 is less than $0.1 \%$ of the original $\mathrm{CO}_{2}$ sample. In the 3 samples of synthesized methane, analyzed by gas chromatography, $\mathrm{CO}_{2}$ was less than $0.1 \%$ in 2 samples and $0.3 \%$ in 1 sample.

Using $\mathrm{H}_{2}$ from 2 sources*, the synthesized methane from "dead" $\mathrm{CO}_{2}$ gave a background counting rate of 1.4 c.p.m. (for $1.5 \mathrm{~L}$ effective volume in an Oeschger counter, filled to $120 \mathrm{~cm} \mathrm{Hg}$ ) - the same as that found with reaction (1) used so far with "dead" water.

In summary, these procedures enable quick and complete synthesis (3 hrs) of large samples (10 to $12 \mathrm{~L}$ ) in one operation. Pure methane, free of hydrogen, is obtained easily and has never required extra purification steps. The trouble-free high-efficiency synthesis rests on the fact that we use amounts of $\mathrm{H}_{2}$ in excess of stoichimetric requirements of 20 to $25 \%$. This amount is an optimum, corresponding to conversion yields close to $100 \%$. We have learned that using $<20 \%$ excess $\mathrm{H}_{2}$ for the reaction synthesis results in incomplete synthesis, with yields ca. 95\%. If $>30 \%$ excess $\mathrm{H}_{2}$ is used, purification of $\mathrm{CH}_{4}$ from excess $\mathrm{H}_{2}$ becomes quite problematic. We underline this here, because, either in reactions (1) or (2) eliminating of excess $\mathrm{H}_{2}$ from the synthesized methane is an acute problem. Recently Buddemier et al. (1970) used a palladium alloy hydrogendiffusion cell to remove excess hydrogen from synthesized methane. Their technique is complicated by self-timed solenoid pumps and palladium cells which are subject to poisoning.

General Comment**: Bagor, a Neolithic site in Rajasthan, was dated to ca. 4500 B.c. (TF-786), thus far the earliest such site in India. The occurrence of copper, in the form of arrowheads, in the 3rd millennium B.c. (TF-1009) is also the earliest reported in India. The 1st millennium B.c. (TF-987) date for the habitation site of Korkai in Tamilnadu is also of special interest.

Of the Late Quaternary samples, TF-1003 is especially important because it dates Middle Stone Age tools found in situ at ca. 20,000 B.c.

The geochemical samples give $\mathrm{C}^{14}$ measurements of bicarbonates of deep ground water. Apparent $\mathrm{C}^{14}$ ages run into thousands of years, indicating the general antiquity of ground water in the deep part of the alluvium. The data provide limiting estimates on the postulated quantities of underground flow from hilly regions. (Detailed paper to be published elsewhere).

\section{ACKNOWLEDGMENTS}

The authors are grateful to D. Lal and Rama, as well as to $\mathrm{H}$. Oeschger (Physik. Inst., Univ. Bern, Switzerland) for helpful suggestions,

* From Messrs. Griesheim GMBH, Dusseldorf, W. Germany and Indian Oxygen Ltd., Oxygen House, T/34 Taratal Road, Calcutta 53.

** Dates referred to in this Comment and apparent ages of geochemical samples, are based on $\tau_{1 / 2}=5730 \mathrm{yr}$. Formal dates for archacologic and geologic dates are reported by the usual convention, $\tau_{1 / 2}=5570 \mathrm{yr}$, as stated in the Introduction. 
and to S. V. Kerkar for assistance. We thank J. Shankar of Bhabha Atomic Research Centre, Bombay, for gas chromotographic analyses.

\section{SAMPLE DESCRIPTIONS}

I. ARCHAEOLOGIC SAMPLES

TF-1019. Ambari, India, historic

$895 \pm 105$

Wood from Ambari (26 $11^{\prime} \mathrm{N}$ Lat, $91^{\circ} 45^{\prime}$ E Long) Dist. Kamrup, an historic site of Gupta and Post-Gupta period, Tr. X 1-2161, Layer 3, depth 1.2 m. Subm. by M. G. Goswami, Dept. of Anthropol., Gauhati Univ., Gauhati. $\mathrm{NaOH}$ pretreatment was given.

\section{Bagor series, Rajasthan}

Bagor (25 $22^{\prime} \mathrm{N}$ Lat, $74^{\circ} 23^{\prime} \mathrm{E}$ Long) Dist. Bhilwara is a Late Stone age site. Comment: only inorganic carbon from charred bones was used for dating, which, however, appear fairly consistent. Subm. by H. D. Sankalia, Deccan College, Poona.

\section{TF-786. Bagor culture}

$6245 \pm 200$

Charred bones, Tr. BGR/E-IV, Layer 2, depth 1.17 to 1.26 m, Field No. BGR-5. Typical geometric microliths with pottery.

\section{TF-1005, -1006. Bagor culture}

Charred bones, Tr. E-11 from depths 0.73 to $0.78 \mathrm{~m}$ and 0.79 to $0.88 \mathrm{~m}$, were mixed; Field Nos. BGR 1968-9E/II-5 and E II-6.

\section{TF-1007. Bagor culture}

$5620 \pm 125$

Charred bones, Tr. E-I, depth 0.99 to $1.1 \mathrm{~m}$, Field No. BGR 19689/E 1-4.

3670 B.C.

TF-1009. Bagor culture

$4585 \pm 105$

Charred bones, Tr. G-III, depth 0.89 to $0.98 \mathrm{~m}$, Field No. BGR 1968 9/G III-12.

\section{TF-1011, -1012. Bagor culture}

Charred bones, Tr. G-V from depths 1.21 to $1.3 \mathrm{~m}$ and 1.31 to $1.4 \mathrm{~m}$, were mixed, Field Nos. BGR 1968-9/G V-18 and GV-19.

\section{TF-989. Bhitari, India, Gupta period}

$$
1620 \pm 90
$$

Charcoal from Bhitari ( $25^{\circ} 32^{\prime} \mathrm{N}$ Lat, $83^{\circ} 15^{\prime} \mathrm{N}$ Long), Dist. Ghazipur, Loc. BTR-2/AO', depth $3.8 \mathrm{~m}$, Field No. BTR-2. Subm. by K. K. Sinha, Banaras Hindu Univ., Varanasi-5. NaOH pretreatment was given. 
Chirand series, Bihar

Chirand $\left(25^{\circ} 45^{\prime} \mathrm{N}\right.$ Lat, $84^{\circ} 45^{\prime} \mathrm{E}$ Long), Dist. Saran, is a Black-andRed ware site. Samples subm. by B. P. Sinha, Dir. Archaeol., Govt. of Bihar, Patna-15. All samples were given $\mathrm{NaOH}$ pretreatment.

TF-1029. Black-and-Red ware deposits $2915 \pm 85$ Charcoal, Layer 10, depth 6.5 m, Field No. CRD XI.

TF-1030. Black-and-Red ware deposits 965 B.C.

Charcoal, Layer 11, depth 6.9 m, Field No. CRD XI.

$3430 \pm 100$

1480 B.c.

TF-995. Inamgaon, India

$1775 \pm 125$

A.D. 175

Charcoal from Inamgaon (18 $35^{\prime} \mathrm{N}$ Lat, $74^{\circ} 32^{\prime} \mathrm{E}$ Long), Dist. Poona, Tr. INM-1, Loc. Tr. $A_{2}$, Layer 3, Field No. 454, subm. by H. D. Sankalia. $\mathrm{NaOH}$ pretreatment was given.

TF-957. Kalibangan, India, Pre-Harappa culture (?) 405 B.c.

$2355 \pm 200$

Wood from Kalibangan (29 $25^{\prime} \mathrm{N}$ Lat, $74^{\circ} 05^{\prime} \mathrm{E}$ Long), Dist. Shri Ganganagar, Loc. ZB8/Qd. 3, 3.15 m, Layer 15, Field No. 1967-68/38/ KLB-1, subm. by Dir. Gen. Archaeol., New Delhi-11. Comment: date, ca. $2000 \mathrm{yr}$, younger than expected.

TF-974. Kayatha, India, Chalcolithic culture

$3485 \pm 95$

\section{B.C.}

Charcoal from Kayatha $\left(23^{\circ} 14^{\prime} \mathrm{N}\right.$ Lat, $76^{\circ} 02^{\prime}$ E Long) Dist. Ujjain, Tr. KTH-B, Layer 19, Field No. KTH-B, 1466, subm. by Z. D. Ansari, Deccan College, Poona-6, $\mathrm{NaOH}$ pretreatment was given.

TF-987. Korkai, India, habitation site

$2680 \pm 90$ 730 в.c.

Wood from Korkai, Dist. Tirunelveli, Loc. 0-1, Layer 5, depth 3.17 m, Field No. KRK-1; subm. by Dir. of Archaeol., Madras-25. NaOH pretreatment was given.

II. GEOLOGIC SAMPLES

TF-902. Porbandar, Pleistocene sediments $35,050+5390$

Shells from sediment of an emerged beach near Porbandar Villa

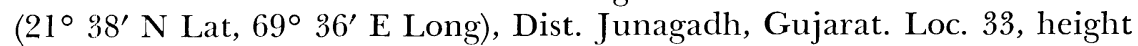
above high water level $3.5 \mathrm{~m}$. Sample 1, subm. by S. K. Gupta. 
TF-1021. Sundernagar, Holocene

Wood fragments from Sundernagar ( $31^{\circ} 32^{\prime} \mathrm{N}$ Lat, $76^{\circ} 33^{\prime} \mathrm{E}$ Long), Dist. Mandi, Himachal Pradesh, subm. by C. P. Vora, Geol. Survey India, Chandigarh. $\mathrm{NaOH}$ pretreatment was given.

III. GEOCHEMICAL SAMPLES

The following samples were collected by members of our Geophysics Group studying groundwater resources. Dissolved bicarbonates from the water were picked up on IR-45 and IRA-400 anion exchange resins. $\mathrm{CO}_{2}$ for dating was then extracted from the resins by eluting them with 1 normal HCl. Results are given as percentage of the modern standard.

\section{Gujarat series}

Subm. by V. N. Nizampurkar.

\begin{tabular}{llcr}
\hline Lab. no. & \multicolumn{1}{c}{ Location } & Depth & \multicolumn{1}{c}{$\begin{array}{c}\delta \mathrm{C}^{14} \\
\text { of Modern }\end{array}$} \\
\hline TF-841 & Kalol, Dist. Mehsana & $187 \mathrm{~m}$ & $64.15 \pm 0.98$ \\
TF-842 & Mansa, Dist. Mehsana & $131 \mathrm{~m}$ & $84.31 \pm 0.90$ \\
TF-843 & Pilvai, Dist. Mehsana & $135 \mathrm{~m}$ & $72.76 \pm 0.95$ \\
TF-845 & Dama, Dist. Banaskantha & $150 \mathrm{~m}$ & $80.21 \pm 0.94$ \\
TF-846 & Deesa, Dist. Banaskantha & dug well & $115.73 \pm 1.25$ \\
\hline
\end{tabular}

\section{Rajasthan series}

Subm. by V. N. Nizampurkar.

\begin{tabular}{lccccc}
\hline Lab. no. & Location & $\begin{array}{c}\text { Well } \\
\text { no. }\end{array}$ & Depth & $\begin{array}{c}\delta \mathrm{C}^{14} \\
\% \text { of Modern }\end{array}$ & $\begin{array}{c}\text { Aquifer no. of } \\
\text { region being } \\
\text { pumped by } \\
\text { tube-well }\end{array}$ \\
\hline TF-1095 & $\begin{array}{c}\text { Bhairwa, Dist. } \\
\text { Jasalmer }\end{array}$ & 3 & $220 \mathrm{~m}$ & $37.64 \pm 0.72$ & Third \\
TF-1096 & $\begin{array}{c}\text { Bhairwa, Dist. } \\
\text { Jasalmer } \\
\text { Bhairwa, Dist. } \\
\text { Jasalmer }\end{array}$ & 4 & $130 \mathrm{~m}$ & $42.39 \pm 0.79$ & First \\
TF-1097 & 5 & $170 \mathrm{~m}$ & $42.88 \pm 0.60$ & Second \\
TF-1121 & $\begin{array}{c}\text { Ajasar, Dist. } \\
\text { Jasalmer } \\
\text { Ajasar, Dist. } \\
\text { Jasalmer }\end{array}$ & - & $88 \mathrm{~m}$ & $11.91 \pm 0.33$ & First \\
TF-1120 & - & $160 \mathrm{~m}$ & $36.27 \pm 0.87$ & Third \\
\hline
\end{tabular}




\section{Uttar Pradesh series}

Subm. by P. S. Daudkhane.

\begin{tabular}{lllr}
\hline Lab. no. & \multicolumn{1}{c}{ Location } & Depth & $\begin{array}{c}\delta \mathrm{C}^{14} \\
\% \text { of Modern }\end{array}$ \\
\hline TF-1038 & $\begin{array}{l}\text { Kakragaor, Dist. Meerut } \\
\left(29^{\circ} \text { N Lat, } 77^{\circ} 12^{\prime} \text { E Long }\right)\end{array}$ & $120 \mathrm{~m}$ & $8.54 \pm 0.33$ \\
TF-1039 & $\begin{array}{l}\text { Shukartal, Dist. Muzaffar Nagar } \\
\left(29^{\circ} 24^{\prime} \text { N Lat, } 78^{\circ} 5^{\prime} \text { E Long) }\right.\end{array}$ & $120 \mathrm{~m}$ & $63.86 \pm 1.04$ \\
TF-1040 & $\begin{array}{l}\text { Darhawali, Dist. Aligarh } \\
\left(28^{\circ} 48^{\prime} \text { N Lat, } 78^{\circ} 5^{\prime} \text { E Long }\right)\end{array}$ & $120 \mathrm{~m}$ & $77.19 \pm 0.90$ \\
TF-1042 & $\begin{array}{l}\text { Bhongaon, Dist. Mainpuri } \\
\left(27^{\circ} 12^{\prime} \text { N Lat, } 79^{\circ} 5^{\prime} \text { E Long }\right)\end{array}$ & $120 \mathrm{~m}$ & $36.14 \pm 0.58$ \\
TF-1043 & $\begin{array}{l}\text { Khanda, Dist. Bulandsahar } \\
\left(28^{\circ} 24^{\prime} \text { N Lat, } 77^{\circ} 54^{\prime} \text { E Long }\right)\end{array}$ & $125 \mathrm{~m}$ & $71.14 \pm 1.20$ \\
\hline
\end{tabular}

\section{REFERENCES}

Agrawal, D. P., Kusumgar, S., and Lal, D., 1965, The measurement of $\mathrm{C}^{14}$ activity and some age determinations of archaeological samples: Current Sci., v. 34, p. 394-397.

Anand, J. S. and Lal, D., 1964, Synthesis of methane from water for tritium measurement: Nature, v. 201, p. 775-777.

Buddemeier, R. W., Young, A. Y., Fairhall, A. W., and Young, J. A., 1970, Improved system of methane synthesis for radiocarbon dating: Rev. Sci. Instruments, v. 41, p. $652-654$.

Burke, W. H., Jr. and Meinschein, W. G., 1955, $\mathrm{C}^{14}$ dating with a methane proportional counter: Rev. Sci. Instruments, v. 26, p. 1137-1140.

Fairhall, A. W., Schell, W. R. and Takashima, Y., 1961, Apparatus for methane synthesis for radiocarbon dating: Rev. Sci. Instruments, v. 32, p. 323-325.

Olson, E. A. and Nickoloff, N., 1965, A system for methane synthesis: Internatl. $\mathrm{C}^{14}$ and $\mathrm{H}^{3}$ dating conf. Proc., Pullman, Washington, June 7-11, p. 41-52.

Polach, H. A. and Stipp, J. J., 1967, Improved synthesis technique for methane and benzene radiocarbon dating: Internatl. Jour. Appl. Radiation and Isotopes, v. 18, p. $359-364$. 